\title{
炎症性疼痛時における $5-\mathrm{HT}_{2 \mathrm{~A}}$ 受容体阻害薬の \\ 脊䯣グルタメートへの影響

\author{
中 野茂 \\ 九州蒾科大学歯科麻酔学講座 (指導：仲西 修教授)
} \\ 平成 12 年 2 月 25 日受理
}

\begin{abstract}
Local 5- $\mathrm{HT}_{2 \mathrm{~A}}$ Receptor Antagonist Attenuates CSF-glutamate Release in Relation to Hyperalgesia Produced by 5-HT Paw Injection in Rats

Shigeru Nakano

Department of Dental Anesthesiology (Director: Prof. Osamu Nakanishi) Kyushu Dental College, Kitakyushu, Japan
\end{abstract}

Serotoninergic neuron located at peripheral sites is thought to be concerned as an one of the pivotal factor of the tissue inflammation which leads to pain behavior. However, which serotonin (5-HT) receptor subtypes is involved in peripheral sensitization is not understood. Sarpogrelate $\mathrm{HCl}$ (MCI) is a novel compound which may modulate inflammatory reaction through $5-\mathrm{HT}_{2 \mathrm{~A}}$ receptor antagonism. No data have still been examined the effect of MCI on inflammatory pain response in relation to spinal glutamate (CSF-Glu) release and that whether this effect is affected to $5-\mathrm{HT}_{2 \mathrm{~A}}$ receptor or not. The present study was designed to evaluate the modulating effect of local administration of $\mathrm{MCI}$ on the instances of flinching behavior and CSF-Glu after 5-HT injection into the rat paw.

Three days after intrathecal implantation of loop-type microdialysis probe in male Sprague -Dawley rats, $100 \mu \mathrm{l}$ of $0.12 \% 5-\mathrm{HT}$ was subcutaneously injected into left hind paw. Thereafter, simultaneous determinations of microdialysis at $10 \mathrm{~min}$. -intervals for glutamate by HPLC-ECD and observation of flinches were performed for $30 \mathrm{~min}$ after subcutaneous administration of either drugs (saline for control, $\mathrm{MCI}, \mathrm{MCI}+\alpha-$ methyl-5-HT)

Flinching behavior after injection of $5-\mathrm{HT}$ in saline groupe were observed (max. 22 flinches/min. at 1-2 $\mathrm{min}$ ). CSF-glu in saline groupe increased by $124 \%$ during the first 10 min. MCI in a dose of $5 \mu \mathrm{g}$ given s. c. attenuated both flinching / min and CSF-glu. But those effects were antagonized by giving a-methyl-5-HT, $5 \mu \mathrm{g}$.

Based on the present study, MCI admistration provokes antinociceptive effect on 5-HTproduced inflammatory pain behaviour in relation to CSF-Glu. These effects were reversed by $5-\mathrm{HT}_{2 \mathrm{~A}}$ receptor agonist, suggesting $\mathrm{MCI}$ has a beneficial effect on hyperalgesia via inhibiting selective $5-\mathrm{HT}_{2 \mathrm{~A}}$ receptor and $\mathrm{CSF}-\mathrm{Glu}$ release.

Key words : 5-HT receptor/MCI/CSF-Glu/Hyperalgesia 


\section{緒言}

末梢の組織障害後には，しばしば痛覚閾值の低下や疼 痛部位の広がり，すなわち “痛覚過敏症”に遭遇する。 しかし，組織障害後の末梢神経系における炎症反応が複 合的であることに加え，求心性侵害受容系の脊䯣におけ る伝達・調節機構が十分に解明されておらず，的確な治 療法もないのが現状である1.

旧来より，末梢の組織障害により， prostaglandine (PGs), bradikinin (BK), noradrenaline (NA) の他, 血小板由来の炎症介在物質 serotonin (5-hydroxytryptanine：5-HT）が放出され，なかでも 5-HT は末梢知 覚神経系に含有する受容体の活性化を介し炎症性疼痛の 発症及びその維持に重要に関与することが考えられてい る ${ }^{2)}$. しかし， よ゙の 5-HT 受容体亜型が介在するのか知 られていない，最近の基礎的研究汃ら，一次求心性無䯣 神経の軸索に 5- $\mathrm{HT}_{2 \mathrm{~A}}$ 受容体の免疫活性が認められ ${ }^{3)}$, ま た後根神経節に李 5- $\mathrm{HT}_{2 \mathrm{~A}}$ を含む 5-HT 受容体亜型の mRNA が局在することが明らかにされだ．さらに，5HT の末梢投与は NA 誘発疼痛を増強し, その作用は 5$\mathrm{HT}_{2 \mathrm{~A}}$ 受容体阻害薬 ketanserin や spiperone で消失す る など，5-HT ${ }_{2 \mathrm{~A}}$ 受容体の関与を示す報告が多い. しか し, 一方では, 末梢 5-HT 皮下注入による疼痛反応は 5$\mathrm{HT}_{1}{ }^{5)}$ ，5-HT ${ }_{2}$ および $5-\mathrm{HT}_{3}{ }^{7)}$ 受容体を介する可能性が in vitro, in vivo の夷験において示唆されている.した がって，未だよ゙の受容体亜型の介在が主であるかについ ては，一定した見解が得られていない。

近年, ラットの脊䯣マイクロダイアリシス法 ${ }^{8}$ が開発 され，これは疼痛反応の観察之同時に末梢からの侵害受 容が脊䯣でどのように伝達されているか, 痛みの伝達物 質放出を湘定することにより痛覚過敏に対する薬物の調 節機構を知るうえで大きな注目を集めている.今まで に, 多くの報告で痛覚過敏に対する薬物の調節機構を知 るのに有用とされている.たとえば，痛覚過敏の調節に， 末梢組織の炎症反応に由来する求心性入力増加を如何に 抑えるかは重要な鍵を握っているが99, 求心性入力の抑 制作用が期待される $\mathrm{Ca}^{2+}$ チャンネル阻害薬, アラキド ン酸カスケードの抑制薬に加え, 5-HT $2 \mathrm{~A}$ 受容体阻害 薬 $^{10-12)}$ の脊髄アミノ酸放出への修飾作用を测定すること により，その調節様式（求心性入力の抑制あるいはシナ プス前抑制作用なよ゙）が分かる.

塩酸サルポクレラート（MCI）は図 1 に示す化学構造 式を有し，いままでに血小板凝集の抑制，抗血栓作用を 介し，末梢循環障害を改善するとされ，またこれらの作

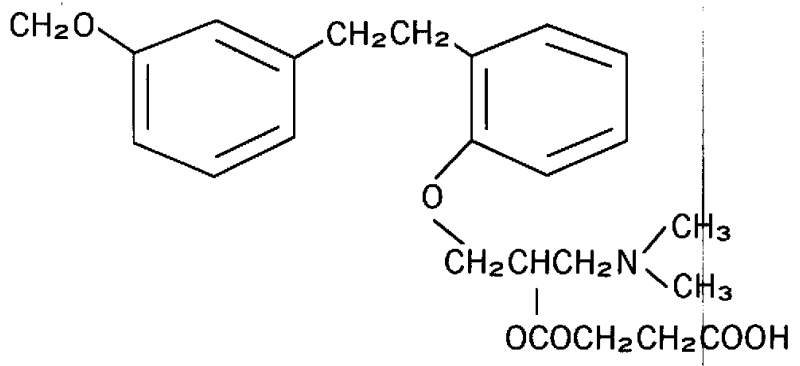

図 1 MCI の化学構造

用は $5-\mathrm{HT}_{2 \mathrm{~A}}$ 受容体作動薬の投与で消失するこ飞が報告 されている(14). したがって，MCI は前述したように末 梢における疼痛発現あるいはその維持機構において，末 梢知覚神経に局在する5- $\mathrm{HT}_{2 \mathrm{~A}}$ 受容体の活性化を抑制 し，侵害受容を抑制する可能性がある，しかし， MCI の 炎症性疼痛に対する鎮痛作用をとくに脊䯣アミ〉酸放出 から調べたものはない。

そこで, 本研究では 5-HT 誘発炎症性疼痛モデルを用 い, MCI 投与後の疼痛行動および脊䯣マイクロダイアリ シス法による脳脊䯣液中グルタメート (CSF-Glu) 変化 を調べた．また同時にその作用は 5-HT $2 \mathrm{~A}$ 受容体選択的 であるかどうか検討をした。

\section{実験方法}

\section{1. 実験動物および準備操作}

実験にはSprague-Dawley ラット（体重 300 $350 \mathrm{~g}$ ） 16 匹を用いた。明/暗 12 時間（明 7 : 00〜19： $00)$ ，室温 $23 \pm 2{ }^{\circ} \mathrm{C}$ 環境条件下で飼育し，固形飼料およ び飲水は自由に与えた。

実験 3 日前にマスクによる酸素とハロタン $(2 \sim 3 \%)$ 麻酔下にループ型マイクロダイアリシス (M. D.) プロー ブを先端が第 $1 \sim 3$ 腰戫部クモ膜下腔内 (I. T.) に位置す るように挿入, 留置しだ).これらの準備操作により, 実 験日において，20\%以上の体重減少，運動障書，アロ ディニアや強いストレス症状の見られるラット㚢実験か ら除外した。 また，実験終了後は速やかに pentobarbital (150 mg/kg) による深麻酔下にて灌流围定を行 い，M. D. プローブの留置位置を確認した（図）.

\section{2. 薬物投与ならびに実験群}

5-HT投与で誘発される炎症性疼痛に先行して，5$\mathrm{HT}$ 投与部位より求心側 $(1-2 \mathrm{~cm})$ 皮下に治療薬を投 与した。薬物投与の種類により，ラットを以下め実験群 に分けた。

A） 5-HT 皮下投与による炎症性疼痛 


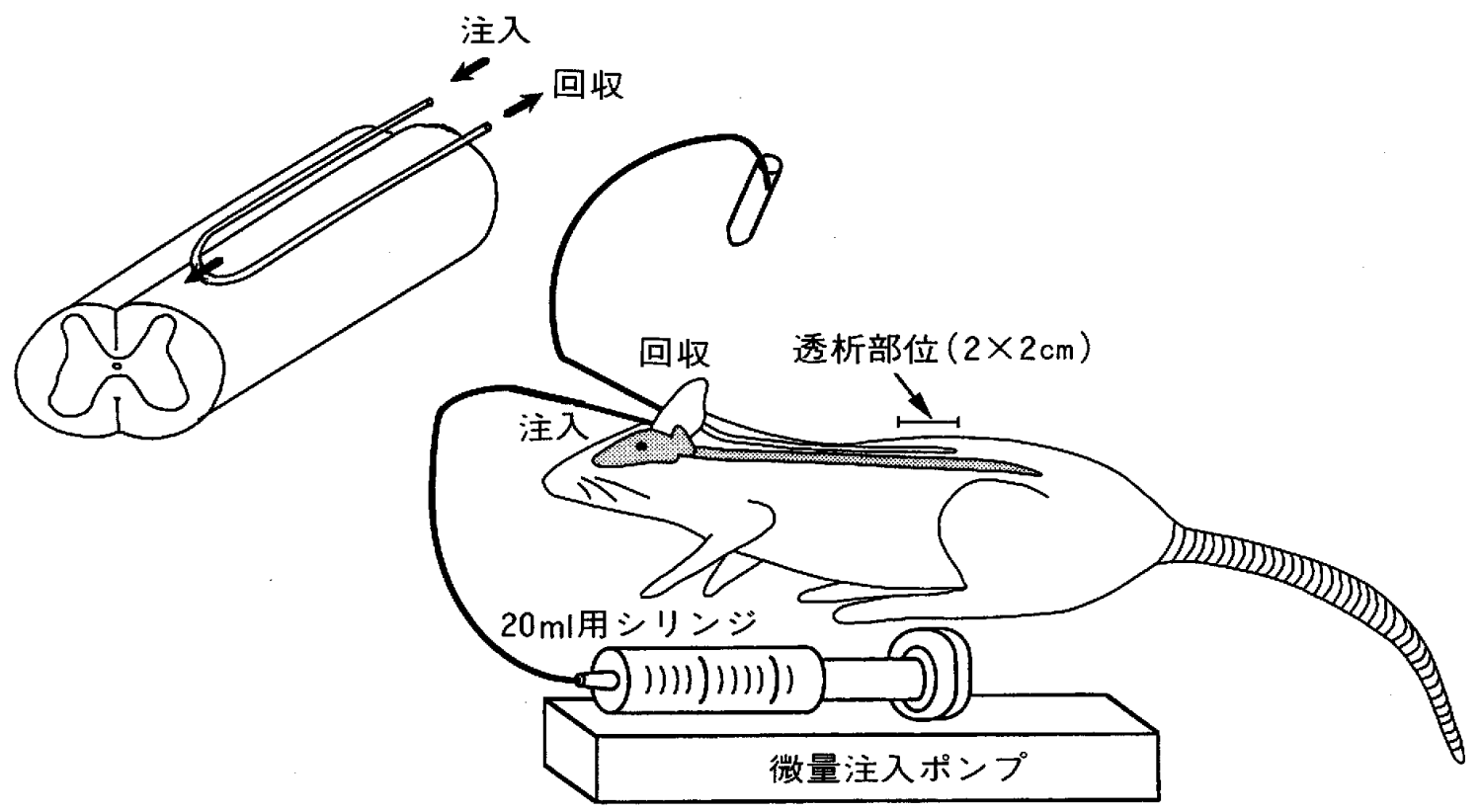

図 2 脊䯣マイクロダイアリシス実験モデル

ラット左後肢の背側部に 5-HT（H-9523, シグマ)を 皮下投与した後, 後肢を引っ込める行動 (flinching) の 分時回数をカウントした.この観察を 30 分間行った. 注 入後 3 分までは 1 分毎, 5 分より 15 分までは 2.5 分毎, 15 分から 30 分までは 5 分毎に行った. まず, 被験薬を 5-HT 注入 5 分前に左後肢の 5-HT 皮下投与部位から上 位 $1 \mathrm{~cm}$ の部位に皮下投与した $(5 \mu 1)$. その後, ラット に $2 \%$ ハロタンと酸素によるマスク麻酔を 2 分間施し鎮 静状態を得た後, 5-HT を $100 \mu 1$ 左後肢甲部に皮下注入 した. 注入後は麻酔を中止し，覚醒後 30 分間にわたり flinching を観察した.

B) 実験群

1. Saline (対照) 群: 生理食塩水 $5 \mu 1$ を投与 $(\mathrm{n}=5)$

2. $\mathrm{MCI}$ 群：MCI $5 \mu \mathrm{g} / 5 \mu \mathrm{l}$ を投与 $(\mathrm{n}=6)$

3. $+\alpha$-methyl-5-HT 群: $\alpha$-methyl-5-hyroxytryptamin maleate $\left(\alpha\right.$-methyl-5-HT: $5-\mathrm{HT}_{2 \mathrm{~A}}$ 作動 楽， $\mathrm{M}-110 ，$ フナコシ) $5 \mu \mathrm{g} / 5 \mu \mathrm{l}$ を併用投与 $(\mathrm{n}=5)$.

3 。使用薬物および調製法

$\mathrm{MCI}$ (塩酸サルポクレラート, 三菱化学) : $5 \mu \mathrm{g} /$ $5 \mu \mathrm{l}, \quad \alpha$-methyl-5HT : $5 \mu \mathrm{g} / 5 \mu \mathrm{l}, \quad 5-\mathrm{HT} ： 120 \mu \mathrm{g} /$ $100 \mu 1$ は原末を蒸留水で溶かし調整した.

4. 脊䯣マイクロダイアリシス

M. D. プローブは，Marsala ら (1995) ${ }^{8)}$ の方法に準じ て作製し, 長さ $18 \mathrm{~cm}$, 透析範囲 $4 \mathrm{~cm}$, 内径 $200 \mu \mathrm{m}$,

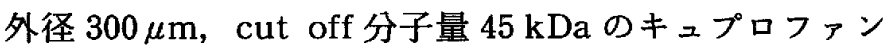

膜ホローファイバーに透析部位以外をエポ L シ樹脂で コーティングして用いた．本プローブの回収率はデキス トロース $(100 \mathrm{mg})$ を用い, $37{ }^{\circ} \mathrm{C}$ 下では約 $40 \%$ であるこ とを予め確かめた．ラットを保定篭（KN 式ボールマン ケージ, 2 型, 夏目製作所) に入れ, 前述の M. D. プローブ の一方に PE-50 チューブ（内径 $0.58 \mathrm{~mm}$, 外径 0.965 , 長さ $30 \mathrm{~cm}$, イントラメデック）を接続し，微量注入ポ ンプを用い, 人工脳脊髄液 (aCSF) $10 \mu \mathrm{l} /$ 分で灌流し た. M. D. プローブの一方に PE-50チューブを接続し透 析液を回収した（図 2). 得られた透析液は CSF-Glu 定 量分析までー $80^{\circ} \mathrm{C}$ で保存した。 $\mathrm{aCSF}$ の組成は, $\mathrm{Na}^{+}$ 151.1, $\mathrm{K}^{+} 2.6, \mathrm{Mg}^{2+} 0.9, \mathrm{Ca}^{2+} 1.3, \mathrm{Cl}^{-} 122.7, \mathrm{HCO}^{3-}$ 21.0, $\mathrm{HPO}^{4-} 2.5$, dextrose 3.5 (単位 $\mathrm{mM}$ ) とした.

安静状態で 30 分間 $\mathrm{ACSF}$ を透析プローブに灌流させ たのち, 透析液を 10 分毎に 2 回採取した. この 2 回の採 取に抢りる平均濃度を基準值（baseline）とし，以後の サンプルは\%baseline で表した. 5-HT 皮下注入後, 痛 覚関連行動を観察しながら 30 分後まで 10 分毎に透析液 を採取した。透析液中の CSF-Glu 濃度は o-phthalaldehyde 誘導体化法を用い，HPLC-ECD（高速液体ク口 マトグラフィー, 電気化学検出器) 法で定量分析した.

\section{5. 統計}

Flinching 回数および CSF-Glu 濃度 (\%baseline) の 测定結果は平均土標準誤差で表した. 5-HT 注入後, 各 時間における flinching 回数の経時的変化および各時間 
における群間の差については, 一元配置分散分析法で判 定し，有意な場合はFisher の最小有意差法を用い，平均 值間について多重比較を行った，危険率 $5 \%$ 以下を有意 とした.

なお，本実験は，「九州歯科大学における動物実験の指 針」に従って行った。

結 果

\section{5-HT 皮下注入後の疼痛関連行動}

Saline 群では， 5-HT の左後肢注入後 1 2 分におい

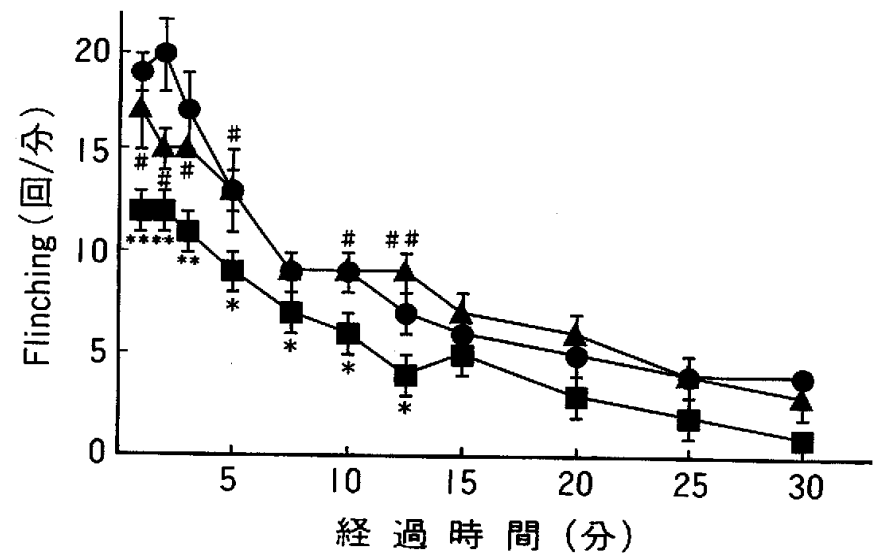

図3 5-HT 皮下投与による疼痛関連行動（flinching）に及ぼ す MCI および $\alpha$-methyl-5-HT の影響

- -Saline 群 - - MCI 群 - MCI $+\alpha$-methyl-5-HT 群

$* * ; \mathrm{p}<0.01$ vs Saline, *: $\mathrm{p}<0.05$ vs Saline, \#; $\mathrm{p}<0.01$ vs $\mathrm{MCI}, \# ; \mathrm{p}<0.05$ vs $\mathrm{MCI}$.

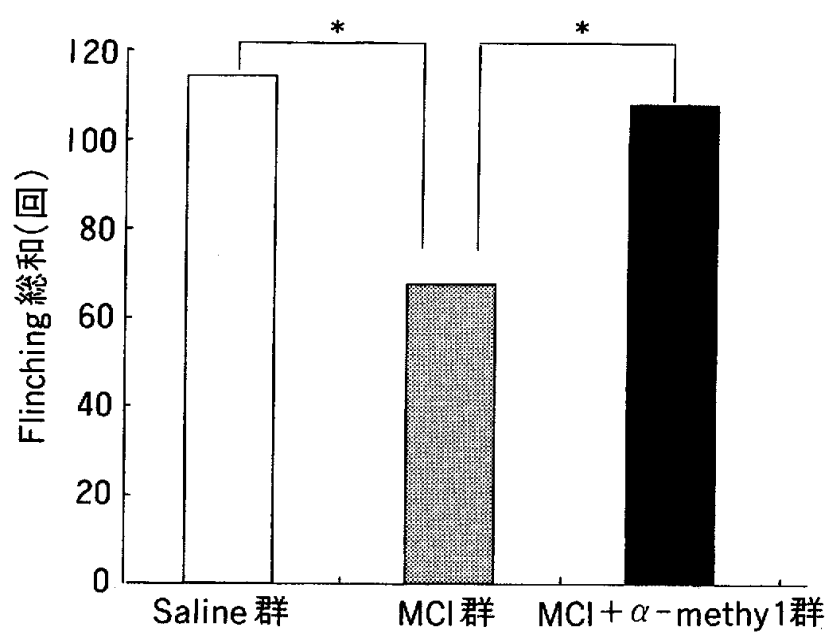

図 4 5-HT 皮下投与後 30 分間における flinching の総和 $*: \mathrm{p}<0.05$
て flinching が平均 20 回/分となるピークを示した. その後は時間之共に減衰し, 30 分後では平均 4 回/分 となるパターンがるられた（図 3). Saline 群の 30 分間 における flinching の総和は 114 回であった. 一方, $\mathrm{MCI}$ 群ではこの flinching のパターンは 1 2 分後で平 均 12 回/分となり有意に抑制され, flinching の総和も 68 回と有意に抑制することが分かった。 また，この MCI の作用は $\alpha$-methyl-5-HT 併用により減少した。 すなわ ち, 1〜2 分後のピークで平均 15 回 / 分, flinching の総 和 108 回となり，MCI に対して有意に拮抗することが分

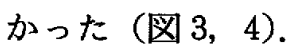

\section{5-HT 注入後の CSF-Glu 濃度の変化}

Saline, MCI, $\alpha$-methyl-5-HT のそれぞれ CSF-Glu の濃度変化に及ぼす影響について結果を（図 5) に示す。 5-HT 注入後の CSF-Glu 濃度変化は\% baseline で示 す. baseline の絶対值は全ての群 $(50-100 \mathrm{pg} / \mathrm{ml})$ の範 囲であった. Saline 群では 5-HT 注入後 CSF-Glu 濃度 は 10 分で\% baseline は $124 \% ， 20$ 分後に $115 \%$ と有 意に増加し，30 分後では baseline に復した. 一方, MCI 投与では，5-HT 投与後 30 分間にわたり baseline に比 べ変化はなく, Saline 群に比べ，10 分および 20 分後に おける値は有意に低值であった. また, $\alpha$-methyl-5-HT 併用では 5-HT 注入後 10 分で\% baseline は $115 \%$, 20 分後で $113 \%$ と有意に増加し， MCI に比べ有意に拮 抗することが分かった（図5）

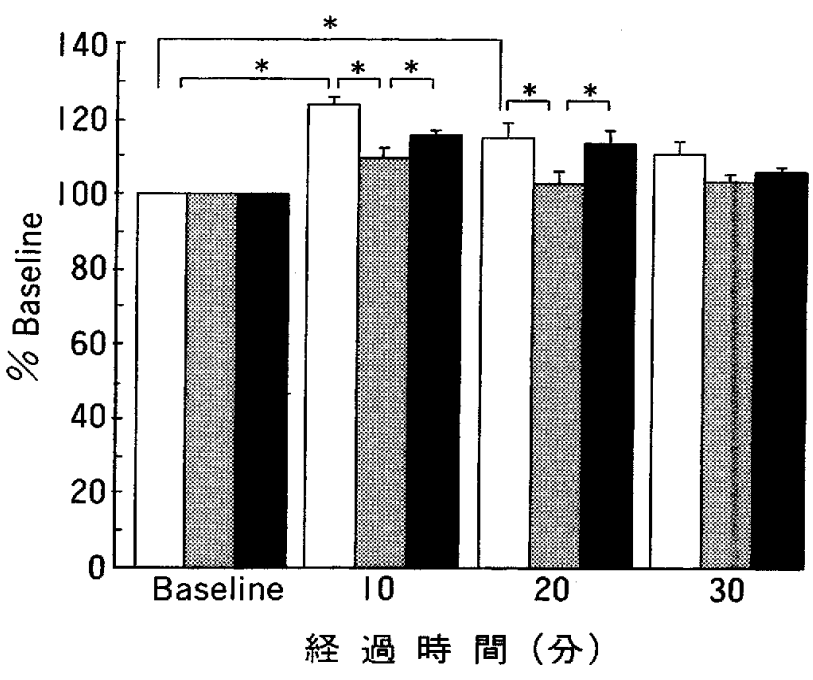

図 5 5-HT 皮下投与後の CSF-Glu 変化（\%Baseline）

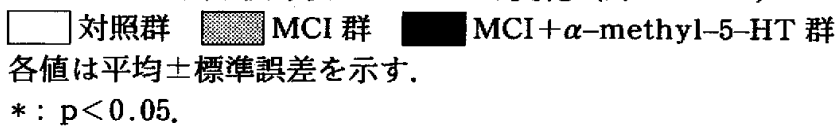




\section{考察}

本研究から，5-HT の皮下注入で誘発される疼痛反応 を 5- $\mathrm{HT}_{2 \mathrm{~A}}$ 受容体阻害薬 $\mathrm{MCI}$ が著しく抑制すること，そ の作用は 5-HT $2 \mathrm{~A}$ 受容体作動薬 $\alpha$-methyl-5-HT で拮抗 されること，また，MCI は 5-HT 皮下注入で誘発される CSF-Glu 濃度増加を抑えることが明かとなった。した がって，炎症性疼痛において，末梢知覚神経線維に局在 する $5-\mathrm{HT}_{2 \mathrm{~A}}$ 受容体の活性化が関与することが脊䯣シナ プス伝達の面よりあ初めて明かになった。

1. 末梢組織障害後の痛覚過敏発生機序

今までに痛覚過敏症の発現には，1）一過性の急性痛 の症状（初期反応：急性痛）を呈した後，脊䯣後角 ニューロンの“神経可塑性”により持続性疼痛反応が現 れること ("中) ("枢性機序”) に加え，2）末梢組織の炎症 反応に起因した知覚神経受容器一求心路系における変調 が末梢の侵害受容器を過刺激し, 求心性侵害刺激情報を 増大し脊䯣に伝達すること（“末梢性機序”）によりもた らされるという 2 面性の機序が考えられている ${ }^{11,12)}$.

前者の場合では，末梢組織障害後に求心性侵害刺激に よって脊髄で神経終末よりグルタミン酸やサブスタンス $\mathrm{P}$ (sP) が放出され，シナプス後細胞の受容体を刺激し細 胞内 $\mathrm{Ca}^{2+}$ 濃度を増加させる結果, ニューロンの感受性 が六進するものと考えられている ${ }^{16,17)}$.また，この細胞内 $\mathrm{Ca}^{2+}$ 濃度の増加は連鎖する細胞内シグナリング反応と してシクロオキシゲナーゼ，Cキナーゼ，一酸化窒素シ ンターゼを活性化し，それぞれ活性物質 PGs，NO 産生
の促進, リン酸化反応を介する受容体の持続的活性化を あたらす ${ }^{18)}$ ．その結果シナプス間隙に過剩放出されたこ れらの活性物質は逆行性にシナプス前細胞を刺激し，神 経伝達物質放出を元進し，さらに脊䯣後角ニューロンの 受容体の持続的活性化から過敏状態，いわゆる“神経可 塑性”を引き起こす。これらのことが，痛みの維持や増 強（痛覚過敏）に関与するあの之理解されつつある（図 6). 本研究は CSF-Glu 濃度を検索することにより従来 の報告では調へらられていなかった脊䯣におけるシナプス 伝達の関与について明らかにしたものである。

一方, 本研究で検討した末梢性機序については，中枢 性機序に比べて未だ十分に解明されていない，今まで に，末梢組織が障害されると炎症反応が起き，遊離され てくる発痛物質が末梢知覚神経線維を刺激し, sP, NA, 5-HT や PGs の放出を促進する．これらは侵害受容器を 過刺激することにより求心性侵害刺激情報の増大をあた らし，中枢で痛みを認識するものと考えられている ${ }^{19,20)}$ (図6).したがって，その治療しして末梢レベルにおけ る求心性入力の炎症反応に由来する増加を如何に抑える かが有用である．中であ 5-HT は，前述したように主要 な炎症介在物質であることから，その抑制薬の臨床応用 を考える上で 5-HT 神経その役割を解明することは有 意義である音。

2. 痛覚過敏と末梢知覚神経における 5-HT 受容体活 性

末梢組織障害後の疼痛を含む病態は，しばしば炎症反 応と関連させ理解されている．したがって，炎症反応を

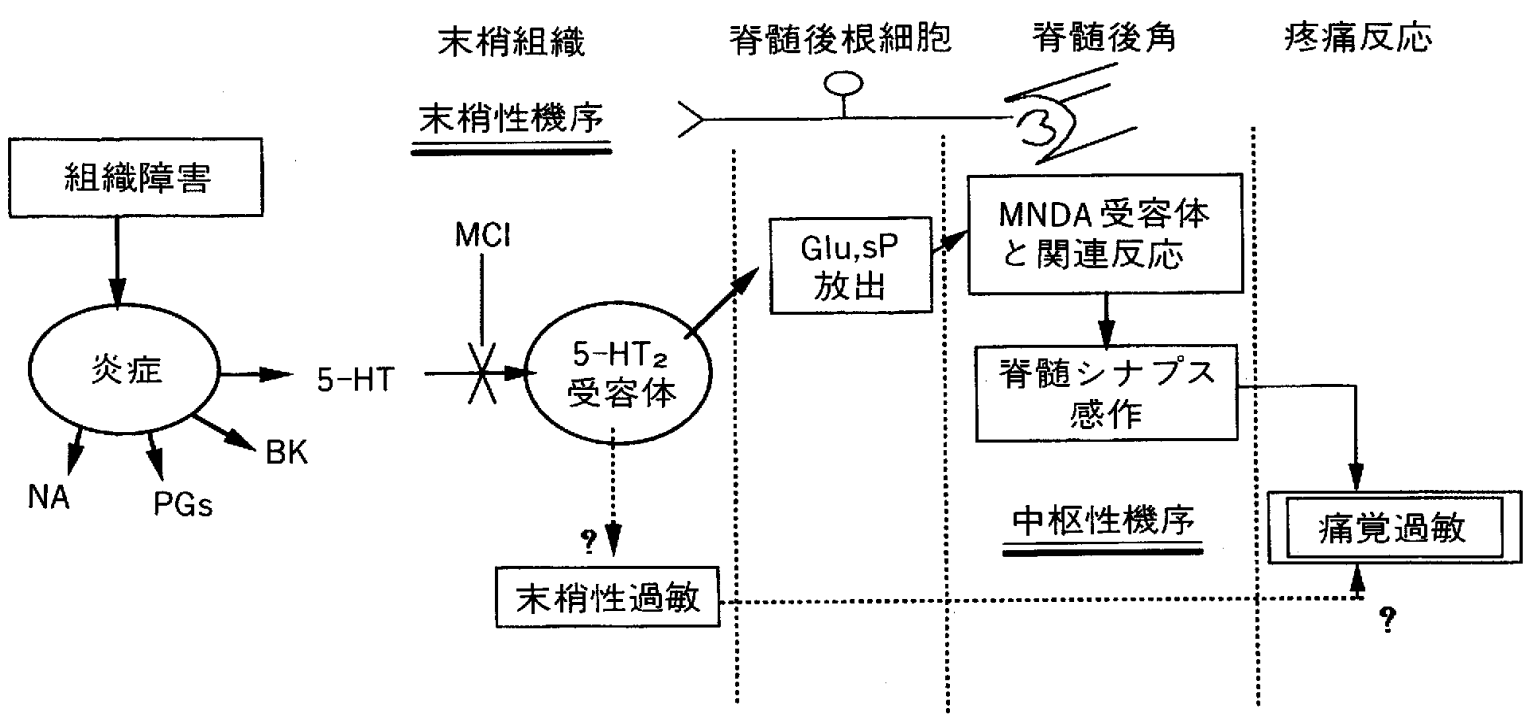

図 6 痛覚過敏の発生機序 
緩和し, 求心性侵害刺激入力の抑制効果をもたらす $\mathrm{Ca}$ チャネル阻害薬，アラキドン酸カスケードの抑制薬（イ ンドメサシンなど）に加え， 5-HT 受容体阻害作用をあ つ薬物の有効性が期待される。ながも，炎症の発生お よび助長因子として主たるあのは 5-HT であり，その炎 症性疼痛への役割を明らかにすることは臨床的にも重要 な意義がある。

そこで本研究では，5-HT 皮下注入の 5 分前に MCI を全身作用を発現し得ない低用量6,10) (5 $\mu \mathrm{g} / \mathrm{body})$ で, 炎症誘発部位に局所投与したところ, MCI は flinching, すなわ咨症性疼痛を抑制し，その作用は $\alpha-$ methyl-5$\mathrm{HT}$ (5- $\mathrm{HT}_{2 \mathrm{~A}}$ agonist) で拮抗された. 一方 CSF-Glu 濃 度は，5-HT 注入後に一過性に上昇したが，MCI はその 増加を抑えることがわかった。

これらの結果から，MCI は 5- $\mathrm{HT}_{2 \mathrm{~A}}$ 受容体阻害作用を 介し，抗痛覚過敏作用を有することが明らかになった。 投与経路および作用様式からその機序を考えると MCI は，1）障害された組織部位において 5-HT 神経の軸索 およびシナプス後細胞に局在する $5-\mathrm{HT}_{2 \mathrm{~A}}$ 受容体を阻害 L，5-HT 神経の興奮性伝達を抑制し，脊䯣への求心性 入力を抑えて効果を発揮するものと示唆される.

しかし，MCI は末梢循環の改善作用を有することも知 られており，障害された知覚神経の栄養供給の改善から 神経機能を損なわなかったために，鎮痛効果が得られた 可能性も否定出来ない，最近，末梢炎症後に血管透過性 が高まり血小板の活性化から 5-HT の放出, 再吸収に続 く微小血栓の発生などの一連のカスケード的反応過程を 調節している末梢 5-HT 神経系については循環器系に 関する検討が著しく進んでいる，すなわち，1）5-HT 受容体が血管内皮細胞に存在し, EDRF（内皮細胞由来 血管弛緩因子）の分泌を促進させ血管を弛緩させ，一方 5- $\mathrm{HT}_{2}$ 受容体は血管平滑筋と血小板に存在し，血管の収 縮，血小板の凝集を起こす ${ }^{13)} .2$ ）とくに血管系において は，末梢の障害血管において血小板の活性化が生じ，5HT が放出される，放出された 5-HT は血小板血栓の形 成を促すとともに，末梢の血管を収縮させる ${ }^{21)}$ 。このこ とは，今後末梢循環を合わせ測定しその関与を調べる必 要があろう。

したがって，これらの示唆的機構と本研究結果を考え 合わせると, 末梢組織障害後の咨症性疼痛の発生は, 末 梢知覚神経終末の 5- $\mathrm{HT}_{2}$ 受容体および末梢血管の 5$\mathrm{HT}_{2}$ 受容体の活性化を介しあたらされること，その場合 MCI は，脊䯣におけるシナプス伝達の抑制（求心性入力 の抑制)をむたらすことが，本研究から初めて明かと
なった.

最近の報告から，5-HT 2 受容体以外の関与を示す報告 あいくつかある. Doak ら $(1997)^{10)}$ はホルマリン皮下 注入でもたらされる痛覚の過敏反応は $5-\mathrm{HT}_{1}$ あるいは $5-\mathrm{HT}_{3}$ 受容体阻害薬で抑制されるが, $5-\mathrm{HT}_{2}$ 受容体阻害 薬では炎症に伴う浮腫は抑制するものの, 痛覚反応の修 飾作用は微弱であることを示し, 本研究結果や前述した 報告 ${ }^{6)}$ とは異なるとした。 このことに加えて， 5- $\mathrm{HT}_{1}$ 受 容体阻害薬 ${ }^{5)}$ ，および $5-\mathrm{HT}_{3}$ 受容体阻害薬 ${ }^{7)}$ が熱的, 機械 的，化学的侵害受容を抑制することあ示唆されている. しかし, 本研究から脊䯣での求心性侵害入力の様子がわ かる脊骾マイクロダイアリシス法を用いた結果, 炎症性 疼痛の発生に $5-\mathrm{HT}_{2}$ 受容体の活性化が関与することを 強く示唆する.

最近, 神経因性疼痛において, MCI がその疼痛を緩和 することが報告されたこと, また慢性疼痛で病態生理学 的状態にある脊䯣局所に大脳縫線核 (5-HT 含有) 細胞 を移植し，治療可能であったとする報告が散見される ${ }^{22)}$. したがって，このような末梢神経系における 5-HT 受容 体の活性化のあたらす細胞の再生, 分化誘導を促し, 痛 覚機能障害の回復をなしえる可能性を追求することは, 今後の研究の展開に大きな影響を与えるものと考える.

\section{まとめ}

ラット 5-HT 皮下注入で炎症性疼痛反応がみらた。こ の疼痛行動は 1 2 分後にピークをもち，その後減衰し 30 分後にはほぼ消失した。この時の CSF-Glu 放出は 20 分まで増加することが明らかになった。また 5- $\mathrm{HT}_{2 \mathrm{~A}}$ 受 容体阻害薬の使用で疼痛行動および CSF-Glu 放出の増 加が抑制され，その作用は 5-HT 2 受容体作動薬併用で 拮抗されることが明かとなった. したがって，このこと より炎症性疼痛の末梢性機序として $5-\mathrm{HT}_{2}$ 受容体の活 性化の関与を示唆された.

稿を終えるにあたりご指導とご校閲を睗わりました恩 師九州歯科大学歯科麻酔学講座仲西 修教授に深甚なる 感謝の意をあらわします.ならびに本研究に数多くのご 協力をいただきました同講座の諸兄姉に心からお礼申し 上げます．

\section{引用文献}

1) Treede, R. D., Meyer, R. A., Raja, S. N. and Campbell, J. N. : Peripheral and central mechanisms of cutaneous hyperalgesia Prog Neurobiol 38: 397-421, 1992. 
2) Rang, H. P., Bevan, S. and Dray, A.: Chemical activation of nociceptive peripheral neurones. Br. Med. Bull 47 : 534-548, 1991.

3) Carlton, S. M. and Coggeshall, R. E.: Immunohistochemical localization of $5-\mathrm{HT}_{2 \mathrm{~A}}$ receptors in peripheral sensory axons in rat glabrous skin. Brain Res. 763 : 271-275, 1997.

4) Pierce, P. A., Xie, G. X., Levine, J. D. and Peroutka, S. J. : 5-Hydroxytryptamin receptor subtype messenger RNAs in rat peripheral sensory and sympathetic ganglia: a polimerase chain reaction study. Neuroscience $70: 553-559,1996$.

5) Rueff, A. and Dray, A.: 5-Hydroxytryptamin-induced sensitization and activation of peripheral fibres in the neonatal rat are mediated via different 5-Hydroxytryptamin receptors. Neuroscience 50 : 899-905, 1992.

6) Abbott, F. V., Hong, Y. and Blier, P.: Activation of $5-\mathrm{HT}_{2 \mathrm{~A}}$ receptors potentiates pain produced by inflammatory mediators. Neuropharmacology 35 : 99$110,1996$.

7) Giordano, J. and Rogers, L. V.: Peripherally admistered serotonin $5-\mathrm{HT}_{3}$ receptor antagonists reduce inflammatory pain in rats. Eur. J. Pharmacol. $170: 83-86,1989$.

8) Marsala, M., Malmberg, A. B., and Yaksh, T. L.: The spinal loop dialysis catheter: characterization of use in the unanesthetized rat. J. Neurosci. Methods 62: 43-53, 1995.

9) Yaksh, T. L.: An introductory perspective on the study of nociception and its modulation in Anesthesia; Biologic foundations, edited by TL Ysksh, Lippincott-Raven Publishers, Philadelphia pp 471-482, 1997.

10) Doak, G. J. and Sawynok, J.: Formalin-induced nociceptive behavior and edema: involvement of multiple peripheral 5-hydroxytriptamin receptor subtypes. Neuroscience 80: 939-949, 1997.

11) Sufka, K. J., Schomburg, F. M. and Giordano, J.: Receptor mediation of 5-HT-induced inflammation and nociception in rats. Pharmacol Biohem Behav. $41: 53-56,1992$.

12) Tokunaga, A., Saika, M. and Senba, E.: $5-H \mathrm{~T}_{2 \mathrm{~A}}$ re- ceptor subtype is involved in the thermal hyperalgesic mechanism of serotonin in the periphery. Pain 76 : 349-355, 1998.

13) Hara, H., Osakabe, M., and Kitajima A., Tamao, Y. and Kikumoto, R.: MCI-9042, a new antiplatelet agent is a selectiveS2-serotonergic rerceptor antagonist. Thrombosis and Haemostasis 65: 415-420, 1991.

14）高野静子：血栓形成におけるセロトニンの役割とセロトニ ン拮抗莧の作用. 基礎と臨床 29 ：S611，1995.

15) Dickenson, A. H. and Sullivan, A. F.: Subcutaneous formalin-induced activity ofdossal horn neurons in the rat-differential respoonse to an intrathecal opiate administered pre or post formalin. Pain 30 : 349-360, 1987.

16) Malmberg, A. B. and Yaksh, T. L.: The effect of morphin on formalin-evoked behaviour and spinal release of excitatory amino acids and prostaglandin $\mathrm{E}_{2}$ using microdialysis in conscious rats. $\mathrm{Br}$. J. Pharmacol 114: 1069-1075, 1995.

17) Yamamoto, T. and Yaksh, T. L.: Comparison of the antinociceptive effects of pre and post treatment with intrathecal morphine and MK801, an NMDA antagonist, on the formalin test in the rat. Anestheology $77: 757-763,1992$.

18) Malmberg, A. B. and Yaksh, T. L.: Cyclooxygenase inhibition and the spinal release of prostaglandin $\mathrm{E}_{2}$ and amino acidsevoked by paw formalin injection: a microdialysis study in unanesthtized rats. J. Neurosci. 15 : 2768-2776, 1995.

19) Hong, Y. and Abbott, F. V. Bihavioural effects of intraplantar injection of inflammatory mediators in the rat. Neuroscience $63: 827-836,1994$.

20) Taiwo, Y. O. and Levine, J. D.: Further confirmation of the role of adenylcyclase and of cAMP-dependent protein kinase in primary afferent hyperalgesia. Neuroscience 44 : 131-135, 1991.

21）原 啓人, 越阪部正徳, 山田久美, 中尾健一郎, 玉尾嘉邦： 血管収縮反応に対する塩酸サルポクレラートの作用，薬理 と治療 19: S611, 1991.

22) Eaton, M. J., Santiago, D. L., Dancausse, H. A. and Whitemore, S. R.: Lumbar transplants of immortalized serotonergic neurons alleviate chronic neuropathic pain. Pain 72: 59-69, 1997. 